\title{
Regulation of cell number in the mammary gland by controlling the exfoliation process in milk in ruminants
}

\author{
L. Herve, ${ }^{*} \dagger$ H. Quesnel, ${ }^{\star} \dagger$ V. Lollivier, ${ }^{\dagger} \dagger \ddagger$ and M. Boutinaud ${ }^{*}{ }^{1}$ \\ *INRA, UMR1348 PEGASE, F-35590 Saint Gilles, France \\ †Agrocampus Ouest, UMR1348 PEGASE, F-35000 Rennes, France \\ fUniversité Européenne de Bretagne, F-35000 Rennes, France
}

\begin{abstract}
Milk yield is partly influenced by the number of mammary epithelial cells (MEC) in the mammary gland. It is well known that variations in MEC number are due to cell proliferation and apoptosis. The exfoliation of MEC from the mammary epithelium into milk is another process that might influence MEC number in the mammary tissue. The rate of MEC exfoliation can be assessed by measuring the milk MEC content through light microscopy, flow cytometry analysis, or an immuno-magnetic method for MEC purification. Various experimental models have been used to affect milk yield and study the rate of MEC exfoliation. Reducing milking frequency from twice to once daily did not seem to have any effect on MEC loss in goat and cow milk after $7 \mathrm{~d}$, but increased MEC loss per day in goats when applied for a longer period. An increase in MEC exfoliation was also observed during short days as compared with long days, or in response to an endotoxin-induced mastitis in cows. Other animal models were designed to investigate the endocrine control of the exfoliation process and its link with milk production. Suppression of ovarian steroids by ovariectomy resulted in a greater persistency of lactation and a decrease in MEC exfoliation. Administering prolactin inhibitors during lactation or at dry-off enhanced MEC exfoliation, whereas exogenous prolactin during lactation tended to prevent the negative effect of prolactin inhibitors. These findings suggest that prolactin could regulate MEC exfoliation. In most of these studies, variations of MEC exfoliation were associated with variations in milk yield and changes in mammary epithelium integrity. Exfoliation of MEC could thus influence milk yield by regulating MEC number in mammary tissue.
\end{abstract}

Received June 15, 2015.

Accepted August 11, 2015.

${ }^{1}$ Presented as part of the Lactation Biology: Mammary Gland Biology Revisited Symposium at the ADSA-ASAS Joint Annual Meeting, Orlando, Florida, July 2015.

${ }^{2}$ Corresponding author: Marion.Boutinaud@rennes.inra.fr
Key words: dairy cow, dairy goat, milk yield, mammary epithelial cell, exfoliation

\section{INTRODUCTION}

The mammary glands of ruminants are made up of a heterogeneous tissue containing various cell populations, including mammary epithelial cells (MEC), myoepithelial cells, fibroblasts, and adipocytes. Mammary epithelial cells are the main cells present in the lactating mammary gland and are responsible for milk synthesis. The number of MEC in the mammary gland and their secretory activity are key factors regulating milk yield. The number of mammary cells in the mammary gland varies throughout lactation, along with variations in milk yield, and is regulated by the balance between cell proliferation and apoptosis. In most species, MEC number increases during early lactation up to peak lactation. After peak lactation, the gradual decrease in milk yield is associated with a decrease in cell number in the mammary gland, due to a greater rate of apoptosis compared with proliferation (Knight and Peaker, 1984; Capuco et al., 2001). Mammary epithelial cell exfoliation can also occur through shedding from the mammary epithelium into milk during lactation. Capuco et al. (2003) suggested that this exfoliation process did not significantly participate in the declining number of mammary secretory cells after peak lactation. From our experiments, however, we estimated that on average $390 \times 10^{6}$ MEC are lost each day by exfoliation in dairy cows. This loss represents $1.6 \%$ of the total MEC number in the udder (M. Boutinaud, unpublished data). Moreover, as will be shown in this review, several physiological, breeding, or environmental factors affect both milk yield and the MEC exfoliation process. Thus, this phenomenon cannot be neglected, as we suspect that the number of MEC in the mammary gland partly depends on the regulation of the exfoliation process. This review summarizes the current knowledge pertaining to MEC exfoliation into milk in ruminants, with emphasis on the factors that influence daily rates of MEC exfoliation. 


\section{THE PROCESS OF MEC EXFOLIATION IN MILK}

\section{MEC in Milk}

Different somatic cell types including leukocytes (lymphocytes, macrophages, neutrophils, and eosinophils) and nonimmune cellular types are present in mammary secretions of all mammals, even those with healthy mammary glands. In human milk, it was shown that the nonimmune cellular types include mature and differentiated epithelial cells and myoepithelial cells, as well as mammary progenitors and stem cells. Differentiated cells originate from the ducts and alveoli of the lactating mammary gland. Stem cells are multipotent and have the ability to differentiate both main mammary epithelial lineages, namely luminal and myoepithelial cells (reviewed by Hassiotou and Hartmann, 2014).

In contrast with human milk where MEC account for more than 90\% of milk somatic cells (Ho et al., 1979), MEC represent a minority of the somatic cell content in ruminant milk. The concentration and proportion of MEC in milk vary between species (Table 1). The concentration of MEC is lower in bovine than in caprine milk (Boutinaud and Jammes, 2002). In ewes, milk MEC represent less than 2 to $3 \%$ of the total somatic cells (reviewed by Bergonier et al., 2003). The presence of MEC has also recently been reported in buffalo (Yadav et al., 2015) and zebu (Janjanam et al., 2013) milk.

Some of the MEC exfoliated into milk are apoptotic cells, but on average 60 to $70 \%$ of milk MEC are viable and exhibit characteristics of fully differentiated alveolar cells (Boutinaud et al., 2013c). Moreover, exfoliated epithelial cells recovered from milk can grow in culture (Ben Chedly et al., 2010; Sorg et al., 2012). The proportion of dying and viable MEC in milk varies between species and experimental models. The MEC exfoliation process thus makes it possible to evacuate both living and dying MEC simultaneously and in various proportions. In humans, it has been hypothesized that MEC were exfoliated from the ductal or luminal layers as a consequence of either a turnover of the secretory tissue or the pressures associated with the continued filling and emptying cycle associated with breastmilk synthesis and breastfeeding (Cregan et al., 2007). Suckling or milking induces a myoepithelial contraction in response to oxytocin release, which in turn, could participate in the exfoliation of MEC. The role of myoepithelial contraction on the MEC exfoliation process has yet to be investigated further.

\section{How to Assess MEC Exfoliation Rate}

The rate of $\mathrm{MEC}$ exfoliation can be defined as the number of MEC lost in milk per day. This rate is estimated by measuring daily milk yield and milk MEC content. Mammary epithelial cell content can be determined through light microscopy, flow cytometry analysis, or an immuno-magnetic method for MEC purification. Regardless of the method chosen, to determine MEC content in milk, the milk must first be defatted and the cells must be pelleted. In the light microscopy method, cells are usually stained to observe the different cellular components (such as the nucleus, cytoplasm, or cytosolic granules) and to recognize the various cellular types (Leitner et al., 2000). For the flow cytometry procedure, cells are incubated with a selective set of monoclonal antibodies to identify each cell type (Leitner et al., 2000), or with an anti-cytokeratin antibody to specifically mark MEC in bovine milk (Wagner et al., 2009). In the immuno-magnetic method, total milk cell suspension is incubated with magnetic beads coated with a specific anti-MEC antibody directed against cytokeratin. Specifically bound cells are collected by placing the sample vials in a magnetic particle concentrator and by aspiration of the supernatant containing leukocytes. Purified milk MEC can be directly counted in a hematocytometer (Ben Chedly et al., 2011) or with a cell counter (Boutinaud et al., 2012). The latter was originally used to purify MEC from human milk (Alcorn et al., 2002) and was

Table 1. Concentration and percentage of mammary epithelial cells (MEC) in ruminant milk

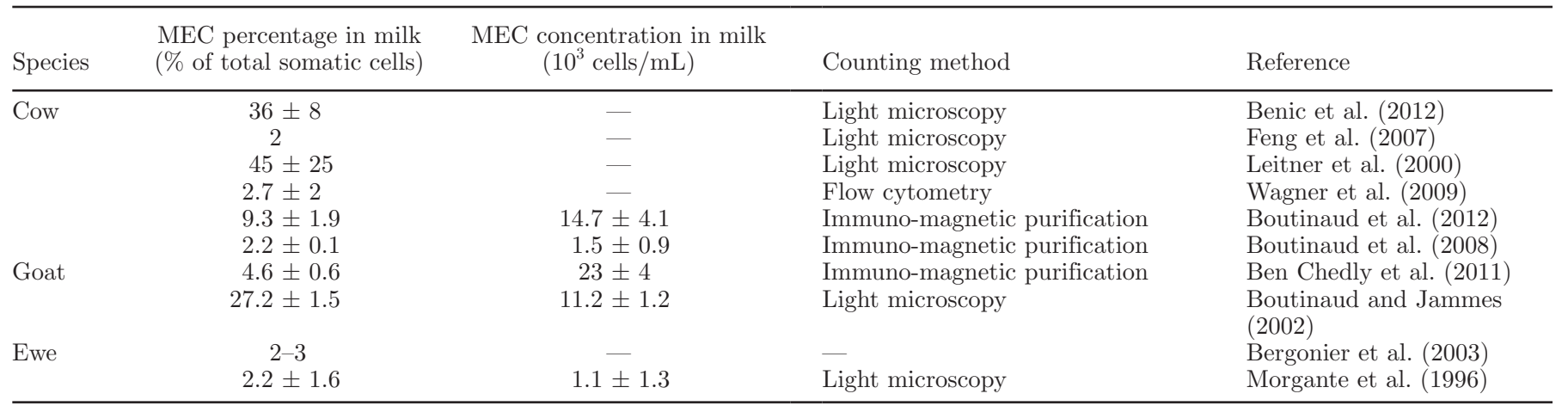


then adapted for bovine milk (Boutinaud et al., 2008). Flow cytometry makes it possible to determine the proportion of MEC relative to total milk cells, while the light microscopy and immuno-magnetic methods allow for the direct counting of MEC, and thus the determination of MEC concentration in milk. Moreover, the immuno-magnetic method has the advantage of being based on a specific antibody used to identify MEC, in contrast with light microscopy.

\section{FACTORS INFLUENCING MILK YIELD AND MEC EXFOLIATION PROCESS IN RUMINANTS}

\section{Female Endocrine Status and Stage of Lactation}

Advancing Lactation and Ovarian Steroids in Cows. Pregnancy during lactation and the associated secretion of estrogens by the fetal-placental unit is known to be linked with a decline in milk yield in lactating cows (Bachman et al., 1988). Furthermore, daily administering of exogenous estradiol with progesterone (Mollett et al., 1976) or alone (Delbecchi et al., 2005) induced a marked decrease in milk yield reaching an $82 \%$ loss of milk $11 \mathrm{~d}$ after the first injection (Delbecchi et al., 2005). Ovarian steroids (i.e., progesterone and estrogens) therefore have a negative effect on milk yield in lactating cows. This decrease in milk yield was not associated with any variation in the expression of genes involved in the regulation of apoptosis such as Bax and Bcl-2 (Delbecchi et al., 2005). On the contrary, suppression of ovarian steroids by ovariectomy at the time of peak lactation improved milk yield by $36 \%$ after 14 mo of lactation and resulted in a greater persistency of lactation with an average daily gain of $2.5 \mathrm{~kg}$ of milk between the 6th and the 14th month of lactation (Yart et al., 2012). Besides its effect on milk yield, ovariectomy significantly decreased the mammary concentration of Poly(ADP-ribose), a protein implicated in DNA fragmentation during the final stage of apoptosis, highlighting that ovariectomy may have reduced apoptosis (Yart et al., 2012). Regarding advancing lactation, the gradual decline of milk yield as lactation progresses was associated with the decreasing MEC number in mammary tissue (Knight and Peaker, 1984). As mentioned above, this MEC loss resulted from an apoptosis rate that was greater than the proliferation rate (Capuco et al., 2001, 2003; Stefanon et al., 2002). To investigate the effect of advancing lactation and ovarian steroids on the rate of MEC exfoliation, 7 cows were ovariectomized approximatively $60 \mathrm{~d}$ postpartum, and 7 control cows were sham-operated. Milk MEC were purified by the immuno-magnetic method at several stages of lactation $(5,21,37,47$, and $54 \mathrm{wk})$. In the sham-operated group, the cows produced 31.2 and $14.3 \mathrm{~kg}$ of milk daily at 21 and 47 wk of lactation, respectively, which represented a $54 \%$ reduction in milk production over time. In parallel, the MEC concentration gradually rose from 3,900 to 46,300 cells $/ \mathrm{mL}$ of milk between 21 and 47 wk of lactation, which represented a $272 \%$ increase in the exfoliation rate as lactation progressed (Table 2, Boutinaud et al., 2013c). In ovariectomized cows, in contrast, the suppression of ovarian steroids tended to increase milk yield and prevented the increased MEC loss that was observed in control cows after $47 \mathrm{wk}$ of lactation (Table 2, Boutinaud et al., 2013c). In conclusion, both advancing lactation and ovarian steroids had a negative effect on milk yield and a stimulatory effect on the exfoliation process.

Prolactin Inhibition During Lactation. In dairy ruminants, prolactin (PRL) roles are controversial. Prolactin was long considered to have a lactogenic rather than a galactopoietic effect (Knight, 2001). Recent experiments, however, demonstrated the essential galactopoietic role of PRL in dairy cows (Lacasse et al., 2012). The effect of PRL on milk yield was studied by using PRL inhibitors, such as cabergoline and quinagolide. These molecules specifically bind the dopamine D2 receptor of the lactotroph, thereby decreasing the synthesis and release of PRL (Brownell, 1996). The effect of a long-term inhibition of PRL was investigated through daily injections of quinagolide for $9 \mathrm{wk}$ (Lacasse et al., 2011; Boutinaud et al., 2012). Milk yield declined in response to the inhibition of PRL secretion and was $14 \%$ lower in quinagolide-treated cows than in control cows. The milk yield loss induced by PRL inhibition in quinagolide-treated dairy cows was partly caused by a decrease in MEC synthetic activity and by a decrease in MEC number, which resulted from a lower proliferation rate and a greater apoptosis rate in the mammary tissue (Boutinaud et al., 2012). The role of PRL on MEC exfoliation has also been studied in a short-term experiment (Lollivier et al., 2015). In this experiment, 9 Holstein dairy cows underwent 3 different treatments for a period of $5 \mathrm{~d}$ each. The first treatment consisted of daily i.m. injections of quinagolide, the second treatment involved daily i.m. injections of quinagolide and daily i.v. injections of bovine PRL, and the third treatment was daily i.m. injections of vehicle (control). Quinagolide treatment reduced milk yield by $10 \%$ in comparison with the control treatment. Prolactin injections in addition to quinagolide tended to increase but did not fully restore milk yield. Compared with the control treatment, the 5-d quinagolide treatment enhanced MEC loss in milk by $60 \%$ (Table 2), whereas exogenous PRL injections tended to prevent the negative effect of quinagolide by limiting the MEC exfoliation rate. Moreover, PRL injections in quinagolide-treated cows significantly increased the proportion of living MEC 
in milk from 57 to $69 \%$. These results are compliant with the in vitro effects of PRL on MEC. Indeed, PRL stimulates MEC proliferation in vitro (Olazabal et al., 2000) and protects MEC from apoptosis by suppressing the expression of an inhibitor of IGF (Accorsi et al., 2002). Together these findings suggest that in addition to its effects on MEC differentiation and apoptosis in mammary tissue, PRL participates in the regulation of MEC number in the mammary gland by regulating the exfoliation process.

Prolactin Inhibition and Mammary Involution. At dry-off, ceasing the milking process caused a rapid decrease in milk secretions, leading to a $90 \%$ decrease in the quantity of milk produced in $7 \mathrm{~d}$ (Hurley, 1989; Wilde et al., 1999). To assess the effect of PRL release inhibition on MEC exfoliation during mammary involution, 14 Holstein dairy cows were injected with a single administration of cabergoline $(\mathrm{n}=7)$ or vehicle $(\mathrm{n}=7)$ just after the last milking before the dry-off (Boutinaud et al., 2013b). Mammary secretion samples were collected using an intraductal teat cannula $6 \mathrm{~d}$ before dry-off $(\mathrm{d}-6)$ and at $1,2,3,4,8$, and $14 \mathrm{~d}$ after dry-off for MEC purification using the immuno-magnetic method. In control cows, the MEC concentration in mammary secretions increased 15 -fold between $d-6$ and 8 . In mammary secretions from cabergoline-treated cows compared with control cows, the proportion of living MEC was decreased 3 and 4 d after dry-off and MEC concentration was $28 \%$ greater $14 \mathrm{~d}$ after dry-off. This experiment confirms that the remodeling of mammary tissue during involution involves the shedding of MEC into the mammary gland cistern, which itself may be regulated by PRL.
Serotonin and Mammary Involution. Serotonin is a hormone and a neurotransmitter known as an autocrine-paracrine regulator of milk secretion in various species (Collier et al., 2012). Serotonin is synthetized and secreted by MEC and has an essential role in the regulation of the mammary gland involution (Matsuda et al., 2004). It is also well known that the first phase of involution in rodents is characterized by a strong increase in cell death by apoptosis and shedding of dying MEC into the alveolar lumen (Watson, 2006; Stein et al., 2007). It have been shown in an immortalized human MEC line and in vivo in mice that serotonin increases milk stasis-induced MEC exfoliation during the first step of mammary involution (Pai and Horseman, 2011). Furthermore, serotonin has been shown to be a feedback inhibitor of lactation in dairy cows because intramammary infusion of serotonin reuptake inhibitor, which increases MEC exposure to serotonin, increased by $11 \%$ the rate of milk decline at dry-off (Hernandez et al., 2008). These findings suggest that serotonin is required for the regulation of mammary cell number, resulting in the regression of the mammary epithelium and the decrease in milk yield associated with involution by inducing both apoptosis and MEC exfoliation.

\section{Management Practices}

Milking Frequency. The lactating mammary gland responds to changes in milking frequency by modulating its milk production. Reducing milking frequency from twice to once daily has been reported to have a negative effect on milk yield in dairy ruminants. Compared with twice-daily milking (TDM), once-daily

Table 2. Influence of various treatments on mammary epithelial cell (MEC) exfoliation process in dairy ruminants

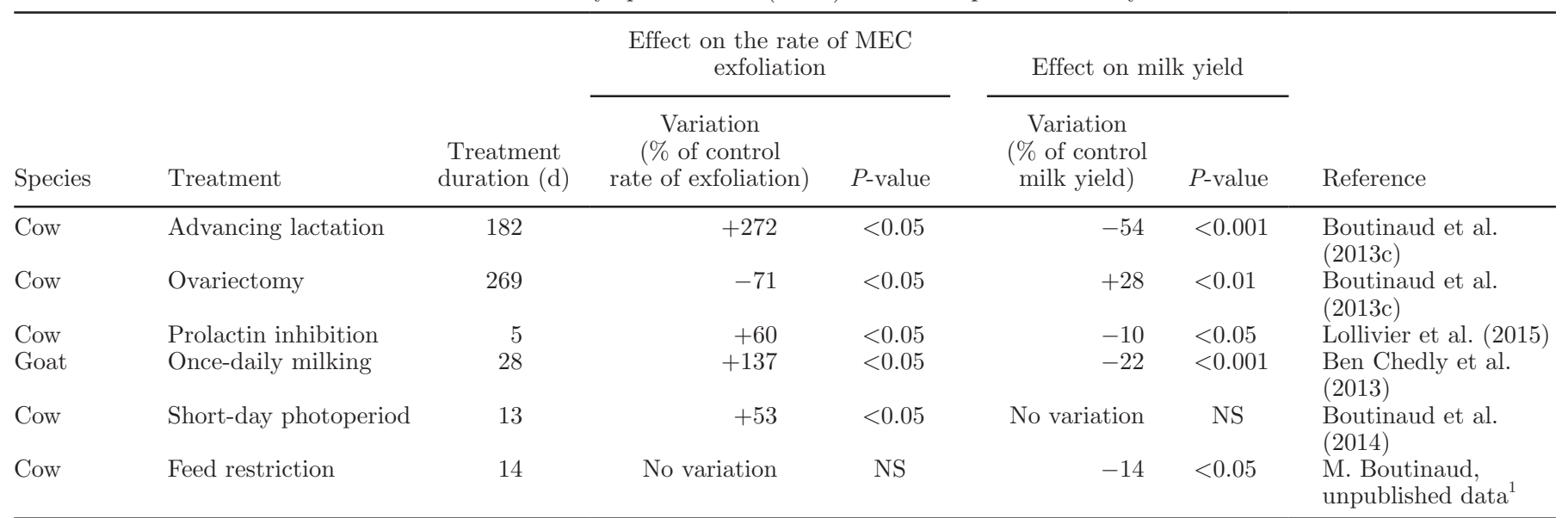

${ }^{1}$ Five multiparous Holstein cows were subjected to a diet that provided either 98 or $70 \%$ of cow requirements and were milked twice daily during $2 \mathrm{wk}$, and then the diets were reversed for the next period. On the 14th day of each 2-wk period, milk samples $(3.5 \mathrm{~kg})$ were collected to isolate total milk somatic cells and purify MEC using magnetic beads coated with an anti-cytokeratin 8 antibody, which is specific to bovine MEC (as described by Boutinaud et al., 2008). 
milking (ODM) reduced daily milk yield by 20 to $30 \%$ in cows (reviewed by Rémond and Pomiès, 2005), by 15 to $48 \%$ in ewes (Knight et al., 1993; Negrao et al., 2001 ), and by 16 to $30 \%$ in goats (Boutinaud et al., 2003; Komara et al., 2009). This decrease in milk yield in goats was associated with a decrease in MEC activity (Ben Chedly et al., 2013). Moreover, changes were clear in cell turnover in the mammary tissue with a lower proliferation rate and a greater apoptosis rate in goats after 4 wk of ODM ( $\mathrm{Li}$ et al., 1999) or in cows after $8 \mathrm{~d}$ of ODM (Boutinaud et al., 2013a). The expression of genes involved in the induction of apoptotic pathways was also increased, which is consistent with the increased apoptosis rate (Littlejohn et al., 2010; Boutinaud et al., 2013a). The effect of milking frequency on MEC exfoliation was investigated in dairy cows and dairy goats. When applied for $7 \mathrm{~d}$, the ODM treatment decreased milk yield but had no effect on milk MEC concentration and exfoliation rate, except for a tendency for a lower rate of MEC exfoliation in one experiment in cows (Table 3). When applied for a longer duration, the ODM treatment influenced MEC exfoliation in dairy goats. In Alpine goats milked twice daily $(\mathrm{n}=6)$ or once daily $(\mathrm{n}=6)$ during $5 \mathrm{wk}$, MEC concentration in milk after $28 \mathrm{~d}$ of treatment was significantly greater in the ODM compared with the TDM group (Ben Chedly et al., 2013). At that time, the daily rate of MEC exfoliation was $137 \%$ greater in the ODM group (Figure 1). After 5 wk of ODM, the dairy goats in the ODM group were switched back to TDM for the 5 following weeks (ODM-TDM group, Ben Chedly et al., 2013). The stimulatory effect of ODM on the exfoliation process was still effective after the switch back to TDM; on the seventh day, the MEC loss per day was $160 \%$ greater in the ODM-TDM group in comparison with the control TDM group (Figure 1), despite similar levels of milk production. The switch back from ODM to TDM might have quickly induced an increase of mammary cell number by stimulating cell proliferation

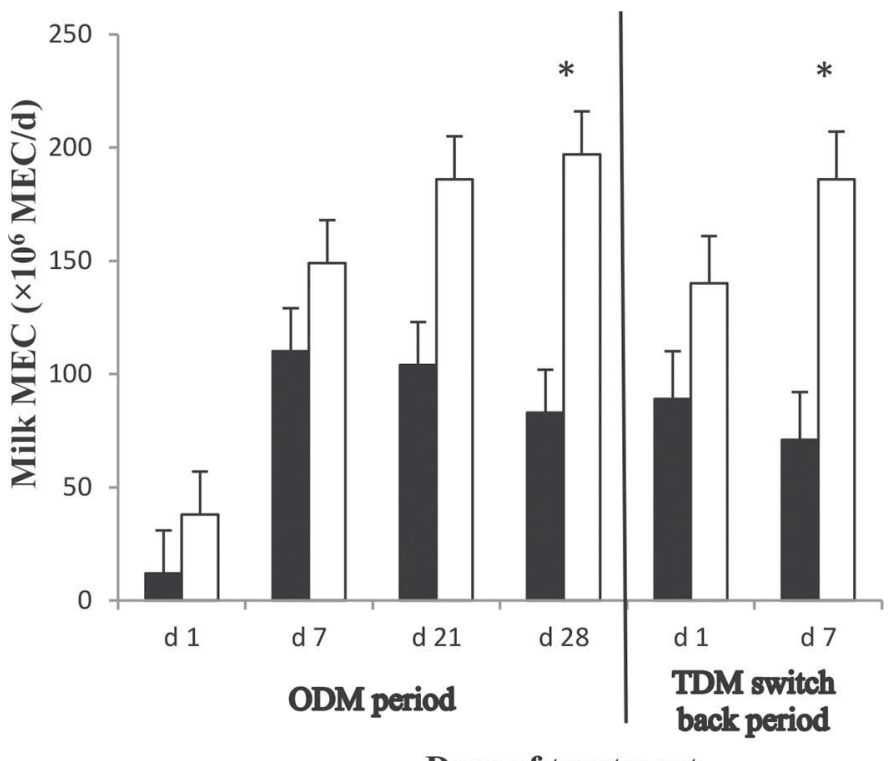

Days of treatment

Figure 1. Rate of mammary epithelial cell (MEC) exfoliation in milk from goats milked once daily (ODM) or twice daily (TDM) during a 28-d ODM period and a 7-d TDM switchback period (Ben Chedly et al., 2013). Data are presented as means \pm standard error of the mean. Statistically different means are indicated by an asterisk for $P<0.05$. Twelve alpine goats were assigned in 2 groups: a control group ( ) that was milked twice daily over all the experiment and a once-daily then twice-daily milking group (ODM-TDM; $\square$ ) that was milked once daily during $5 \mathrm{wk}$ and switched back to TDM for the next 5 wk (as described in Ben Chedly et al., 2013). Milk samples were collected on the 1st, 7th, 21th, and 28th day of the ODM period and the 1st and 7th day of the TDM switchback period for MEC purification using magnetic beads coated with an anti-cytokeratin 8 antibody. The milk MEC concentration was measured with a Vi-CELL XR analyzer (Beckman Coulter, Roissy, France) to assess the number of milk MEC exfoliated per day.

(reviewed by Wall and McFadden, 2012) or reducing cell death, or both, which might explain the restoration of milk yield. Simultaneously, the switch back could have also induced a mammary tissue remodeling with a removal of senescent MEC via the exfoliation process.

Table 3. Effect of once-daily milking (ODM) for $7 \mathrm{~d}$ compared with twice-daily milking (TDM) on mammary epithelial cell (MEC) concentration in milk and MEC exfoliation rate

\begin{tabular}{|c|c|c|c|c|c|c|c|}
\hline \multirow[b]{2}{*}{ Species } & \multicolumn{3}{|c|}{$\begin{array}{l}\text { Milk MEC concentration } \\
\quad\left(10^{3} \text { cells } / \mathrm{mL}\right)\end{array}$} & \multicolumn{3}{|c|}{$\begin{array}{l}\text { MEC exfoliation rate } \\
\left(10^{6} \text { cells } / \mathrm{d}\right)\end{array}$} & \multirow[b]{2}{*}{ Reference } \\
\hline & ODM & TDM & $P$-value & ODM & TDM & $P$-value & \\
\hline Cow & 14.1 & 20.9 & NS & 274 & 469 & 0.15 & M. Boutinaud, unpublished data ${ }^{1}$ \\
\hline Goat & 23.4 & 13.2 & NS & 19 & 8 & NS & Ben Chedly et al. (2011) \\
\hline Goat & 55.0 & 29.0 & NS & 149 & 110 & NS & Ben Chedly et al. (2013) \\
\hline
\end{tabular}

${ }^{1}$ Five multiparous Holstein cows were either once-daily milked (24-h milking interval) or twice-daily milked (12-h milking interval) for 1 wk. The following week, the milking frequency was reversed. On the seventh day of each week, milk samples $(3.5 \mathrm{~kg})$ were collected to isolate total milk somatic cells and purify MEC using magnetic beads coated with an anti-cytokeratin 8 antibody, which is specific to bovine MEC (as described by Boutinaud et al., 2008). 
Together these findings suggest that the decrease in milk yield during ODM treatment could be due to a decrease in the synthetic activity of MEC and changes in MEC turnover in the short term. In the longer term, the MEC exfoliation process may play a role in adjusting MEC number in the mammary gland in response to different milking frequencies.

Photoperiod. In ruminants, photoperiod highly influences lactation. Compared with a short-day photoperiod, a long-day photoperiod was associated with an increase in milk yield, from +0.5 to $+3.3 \mathrm{~kg} / \mathrm{d}$, in lactating cows (reviewed by Dahl et al., 2000), along with greater circulating concentrations of the galactopoietic hormone IGF-I (Dahl et al., 2012) and basal serum concentrations of PRL (Peters et al., 1981). This galactopoietic response to long-day photoperiod was observed at all stages of lactation (Dahl and Petitclerc, 2003). In dairy goats, a long-day photoperiod corresponding to $16 \mathrm{~h}$ of light exposure increased milk yield by $20 \%$ at the end of the lactation (Russo et al., 2013).

To investigate the photoperiodic effect on MEC exfoliation into milk, dairy cows were exposed to a shortday or a long-day photoperiod corresponding to 8 or 16 $\mathrm{h}$ of light exposure, respectively, for $14 \mathrm{~d}$ (Boutinaud et al., 2014). In this experiment, the photoperiod had no significant effect on milk yield, likely because of the short treatment duration. Indeed, the galactopoietic response to longer days is a gradual response and was shown to be significant only after 3 to $4 \mathrm{wk}$ of exposure (Dahl and Petitclerc, 2003). Contrary to milk yield, the exfoliation process was influenced by the 2 wh of light treatment exposure (Boutinaud et al., 2014). On the 13th day of treatment, the number of MEC exfoliated in milk daily was significantly greater during short rather than long days ( 239 vs. $156 \times 10^{6}$ cells/d), representing an increase of $53 \%$ in exfoliation rate (Table 2). This effect could be linked to the lower concentrations of IGF-I and PRL during short days, 2 hormones known to act as survival factors and preventing cell death by apoptosis (reviewed by Flint and Knight, 1997).

Diet. Diet is one of the main factors affecting milk yield in dairy ruminants. In dairy cows, a severe feed restriction from $2 \mathrm{wk}$ before calving to $11 \mathrm{wk}$ postpartum induced a $38 \%$ milk loss in comparison with cows fed a standard diet (Dessauge et al., 2011). This milk loss was associated with a decrease in mammary gland weight by $38 \%$, smaller alveoli, and an increase in apoptotic rate (Dessauge et al., 2011). To our knowledge, the effect of feed restriction on MEC exfoliation has only been investigated once. Cows were subjected to a diet that provided $70 \%$ of cow requirements during 2 wk (as described by Boutinaud et al., 2008). Feed restriction reduced milk yield without affecting MEC loss in milk
(Table 2). The effect of a long-term feed restriction on MEC exfoliation needs to be investigated.

Infection Status. The infection status, specifically mastitis, is a major factor that increases SCC in milk, mainly due to the influx of leukocytes from blood to milk in response to IMI. For this reason, the SCC is used in dairy industry as an indicator of milk quality and udder health. The proportion of each cell type also depends on the presence or the absence of a mastitic pathogen (Morgante et al., 1996; Leitner et al., 2000). Mastitis is also known to have a temporary negative effect on milk production. In dairy cows, endotoxininduced mastitis induced a $17 \%$ milk loss $11 \mathrm{~h}$ after the infusion (Shuster et al., 1991). This reduced ability of mammary glands with mastitis to synthesize and secrete milk is related to a disruption of MEC integrity, sloughing of cells, and increased apoptosis (reviewed by Akers and Nickerson, 2011). In cows with endotoxininduced mastitis, the percentage of milk MEC measured by cytometry analysis increased from $3 \%$ of the total milk somatic cells to $42 \% 12 \mathrm{~h}$ after endotoxin administration (Wagner et al., 2009). This effect on the percentage of MEC in milk suggests that endotoxins may damage the mammary epithelium, resulting in a massive MEC exfoliation during the early phase of mastitis.

In most of the experiments described in the present review, MEC exfoliation varied together with milk yield, decreasing when milk yield increased and vice versa (Table 2). This finding supports our hypothesis that the MEC exfoliation process may participate in regulating MEC number in the mammary tissue, together with the proliferation-apoptosis balance. Current findings also suggest that variations in the exfoliation rate and in milk yield can be slightly decoupled in time. During a short-day photoperiod treatment, the MEC exfoliation rate rose before any decrease in milk yield was observed, suggesting that the change in milk yield during photoperiod manipulation could be the consequence of a change in MEC exfoliation. In contrast, during an ODM treatment, the decrease in milk yield preceded the enhancement of MEC exfoliation. This is consistent with the fact that milk yield is regulated by numerous biological mechanisms.

\section{THE LINK BETWEEN MEC EXFOLIATION AND MAMMARY EPITHELIUM INTEGRITY}

The mammary epithelium is composed of a unique layer of jointed MEC. Tight junctions (TJ) are extracellular structures located in the apical domain of MEC that form a barrier between 2 adjacent secretory cells and ensure epithelium integrity (Figure 2). These TJ 
are dynamic structures that can open and seal quickly in response to changing physiological stimuli (Stelwagen et al., 1997). The disruption of TJ causes a loss of mammary epithelium integrity and allows the crossing of milk components into blood and blood components into milk (Figure 2). Several markers can therefore be measured to indirectly assess mammary epithelium integrity: plasma concentrations of lactose, milk con- centrations of $\mathrm{Na}$ and $\mathrm{K}$ (and the $\mathrm{Na} \mathrm{K}$ ratio) and albumin, and the casein:whey ratio in milk (Stelwagen et al., 1994; Ben Chedly et al., 2013). In cows and goats, the disruption of TJ results in a significant decrease in milk yield (Stelwagen et al., 1995; Ben Chedly et al., 2010) associated with a reduction of MEC synthetic activity and an increase in cell death by apoptosis in mammary tissue (Ben Chedly et al., 2010).

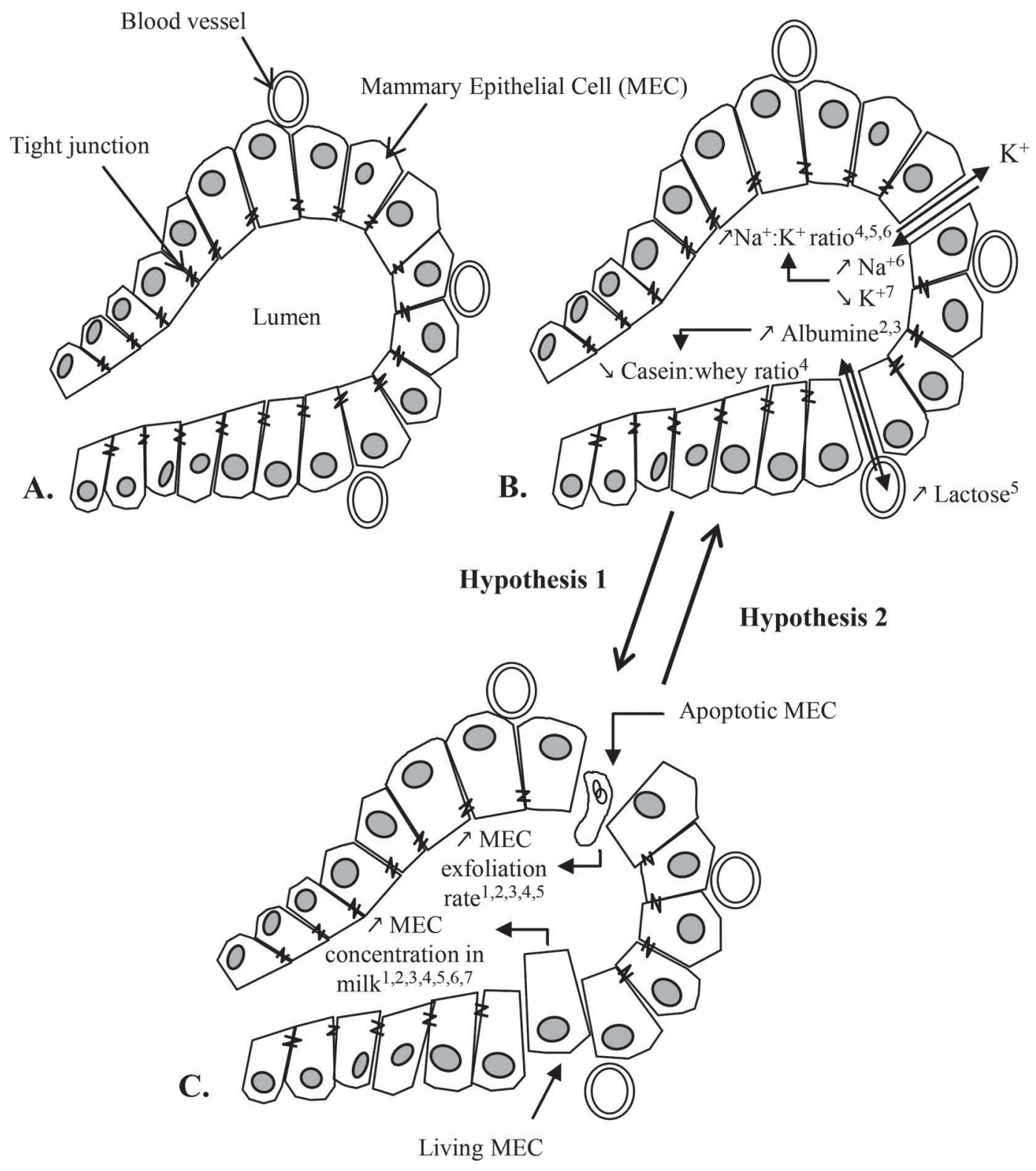

Figure 2. Schematic representation of a mammary alveolus (A) and summary of the effects of breeding and endocrine factors on the mammary epithelium integrity (B) and on the exfoliation process (C). The factors affecting the mammary epithelium integrity (B) and the exfoliation process (C) are (1) prolactin inhibition during lactation (Lollivier et al., 2015); (2) control versus ovariectomy (Yart et al., 2012; Boutinaud et al., 2013c); (3) advancing lactation (Yart et al., 2012; Boutinaud et al., 2013c); (4) twice-daily milking versus once-daily milking (Ben Chedly et al., 2013); (5) short-day versus long-day photoperiod (Boutinaud et al., 2014); (6) mammary involution (Boutinaud et al., 2013b); and (7) prolactin inhibition during mammary involution (Boutinaud et al., 2013b). Mechanisms underlying the link between mammary epithelial cell (MEC) exfoliation and mammary epithelium integrity remain to be deciphered. Mammary epithelial cell exfoliation could be a consequence of (hypothesis 1) or a cause for the disruption of epithelium integrity (hypothesis 2). 
Variations in mammary epithelium integrity have been observed concomitantly to changes in MEC exfoliation in response to different endocrine, breeding, or environmental factors. First, several markers cited above indicated that ODM treatment caused a TJ disruption (Stelwagen et al., 1994; Ben Chedly et al., 2013). In goats, the 28-d ODM treatment induced a decrease in the casein:whey ratio in milk, suggesting a TJ opening, which was concomitant with the increase in the exfoliation rate (Ben Chedly et al., 2013). After the switch back from ODM to TDM for $14 \mathrm{~d}$, the mammary epithelium was still disrupted as indicated by a lower casein:whey ratio, which could explain the fact that the stimulatory effect of ODM on MEC exfoliation process was still effective (Ben Chedly et al., 2013). The exfoliation rate and epithelium integrity were also affected by the endocrine status of the female. The increased MEC exfoliation rate as lactation progresses was associated with more disrupted TJ, whereas the lower MEC exfoliation rate in response to ovariectomy was associated with closed TJ (Boutinaud et al., 2013c). These results were compliant with the fact that progesterone was shown to inhibit TJ closure in rodents (Nguyen et al., 2001). At dry-off, the enhancement of MEC concentration in mammary secretions was concomitant with an opening of TJ, indicated by an increase in albumin concentrations and in the $\mathrm{Na}: \mathrm{K}$ ratio in milk (Boutinaud et al., 2013b). Furthermore, the lower MEC concentration in mammary secretions from cabergoline-treated cows compared with control cows was associated with a tendency toward an increase in TJ opening, supported by a decreased Na:K ratio. Serotonin, known to increase milk stasis-induced MEC exfoliation during involution in rodents, is also known to disrupt TJ in different MEC lines including bovine and in vivo in dairy cows (Stull et al., 2007; Hernandez et al., 2011). Finally, in comparison with long days, short days were associated with more disrupted TJ, concomitantly with the higher MEC exfoliation rate (Boutinaud et al., 2014).

The concomitant increase in MEC exfoliation and in the disruption of mammary epithelium integrity may be interpreted in 2 ways. The exfoliation of living and dying MEC could be a consequence of an induction of the TJ opening (Figure 2; hypothesis 1). Mammary epithelial cells disconnected from each other may be shed from the epithelium into milk. This could be the case when the exfoliation process is modified by changes in the endocrine status, because multiple hormones - such as glucocorticoids, PRL, progesterone, serotonin, and oxytocin - are known to influence mammary epithelium integrity (Nguyen and Neville, 1998; Stelwagen et al., 1999; Werner-Misof et al., 2007). The second hypothesis (Figure 2) is that MEC exfoliation could be the cause of alterations in epithelium integrity. Mammary epithe- lial cell shedding may leave gaps in the epithelium that alter its integrity. It is likely that the 2 mechanisms occur simultaneously. In between milking, the shedding of MEC from the basement membrane into the lumen could occur as a result of cell death induction or be induced by anchorage-dependent detaching of cells from the surrounding extracellular matrix after disruption of epithelium integrity. During milking, MEC shedding could be reinforced by myoepithelial cell contraction.

\section{CONCLUSIONS}

The presence of MEC in milk proves that some MEC are shed from the mammary epithelium. The MEC exfoliation rate has been shown to vary in response to different physiological, breeding, and environmental factors. Most variations in the MEC exfoliation rate in response to these factors were associated with opposite variations in milk yield. This supports the fact that, in addition to changes in the proliferation-apoptosis balance, the exfoliation of MEC from the epithelium into milk is another process that could influence MEC number in mammary tissue. Finally, some evidence exists that the exfoliation rate is linked with mammary epithelium integrity and could be a cause for - or a consequence of - a tight junction opening. Special attention should be paid to the mechanisms regulating MEC exfoliation, especially the proportion of living and dying MEC in milk.

\section{REFERENCES}

Accorsi, P. A., B. Pacioni, C. Pezzi, M. Forni, D. J. Flint, and E. Seren. 2002. Role of prolactin, growth hormone and insulin-like growth factor 1 in mammary gland involution in the dairy cow. J. Dairy Sci. 85:507-513.

Akers, R. M., and S. C. Nickerson. 2011. Mastitis and its Impact on Structure and Function in the Ruminant Mammary Gland. J. Mammary Gland Biol. Neoplasia 16:275-289. http://dx.doi. org/10.1007/s10911-011-9231-3.

Alcorn, J., X. Lu, J. A. Moscow, and P. J. McNamara. 2002. Transporter gene expression in lactating and nonlactating human mammary epithelial cells using real-time reverse transcriptionpolymerase chain reaction. J. Pharmacol. Exp. Ther. 303:487-496. http://dx.doi.org/10.1124/jpet.102.038315.

Bachman, K. C., M. J. Hayen, D. Morse, and C. J. Wilcox. 1988. Effect of pregnancy, milk yield, and somatic cell count on bovine milk fat hydrolysis. J. Dairy Sci. 71:925-931.

Ben Chedly, H., M. Boutinaud, P. Bernier-Dodier, P.-G. Marnet, and P. Lacasse. 2010. Disruption of cell junctions induces apoptosis and reduces synthetic activity in lactating goat mammary gland. J. Dairy Sci. 93:2938-2951. http://dx.doi.org/10.3168/jds.20092678.

Ben Chedly, H., P. Lacasse, P.-G. Marnet, and M. Boutinaud. 2013. The decrease in milk yield during once daily milking is due to regulation of synthetic activity rather than apoptosis of mammary epithelial cells in goats. Animal 7:124-133. http://dx.doi. org/10.1017/S1751731112001176.

Ben Chedly, H., P. Lacasse, P.-G. Marnet, M. Komara, S. Marion, and M. Boutinaud. 2011. Use of milk epithelial cells to study regulation 
of cell activity and apoptosis during once-daily milking in goats. Animal 5:572-579. http://dx.doi.org/10.1017/S1751731110002284.

Benić, M., B. Habrun, G. Kompes, Ž. Mihaljević, Ž. Cvetnić, M. Cergolj, and N. Maćešić. 2012. Cell content in milk from cows with S. aureus intramammary infection. Veterinarski Arhic 82:411-422.

Bergonier, D., R. de Crémoux, R. Rupp, G. Lagriffoul, and X. Berthelot. 2003. Mastitis of dairy small ruminants. Vet. Res. 34:689-716. http://dx.doi.org/10.1051/vetres:2003030.

Boutinaud, M., M. H. Ben Chedly, E. Delamaire, and J. GuinardFlament. 2008. Milking and feed restriction regulate transcripts of mammary epithelial cells purified from milk. J. Dairy Sci. 91:988998. http://dx.doi.org/10.3168/jds.2007-0587.

Boutinaud, M., A. Boudon, J. Couedon, M. Johan, A. Narcy, and C. Hurtaud. 2014. Daylength affects simultaneously mammary epithelium integrity and mammary epithelial cell exfoliation in milk. J. Anim. Sci. 92(E-Suppl. 2):202. (Abstr.)

Boutinaud, M., L. Galio, V. Lollivier, L. Finot, S. Wiart, D. Esquerre, and E. Devinoy. 2013a. Unilateral once daily milking locally induces differential gene expression in both mammary tissue and milk epithelial cells revealing mammary remodeling. Physiol. Genomics 45:973-985. http://dx.doi.org/10.1152/physiolgenomics.00059.2013.

Boutinaud, M., N. Isaka, A. Deflandre, E. Gandemer, P.-G. Marnet, F. Dessauge, and V. Lollivier. 2013b. Prolactin-inhibitor cabergoline enhanced the mammary remodeling during drying-off in dairy cows. J. Dairy Sci. 96(E-Suppl. 1):151.

Boutinaud, M., and H. Jammes. 2002. Potential uses of milk epithelial cells: A review. Reprod. Nutr. Dev. 42:133-147. http://dx.doi. org/10.1051/rnd:2002013.

Boutinaud, M., V. Lollivier, L. Finot, R. M. Bruckmaier, and P. Lacasse. 2012. Mammary cell activity and turnover in dairy cows treated with the prolactin-release inhibitor quinagolide and milked once daily. J. Dairy Sci. 95:177-187. http://dx.doi.org/10.3168/ jds.2011-4461.

Boutinaud, M., C. Rousseau, D. H. Keisler, and H. Jammes. 2003. Growth hormone and milking frequency act differently on goat mammary gland in late lactation. J. Dairy Sci. 86:509-520.

Boutinaud, M., L. Yart, P. Debournoux, S. Wiart, L. Finot, E. Le Guennec, P.-G. Marnet, F. Dessauge, and V. Lollivier. 2013c. Exfoliation of mammary epithelial cells in milk is linked with lactation persistency in dairy cows. Page 503 in Book Abstr. 64th Annu. Meet. Eur. Fed. Anim. Sci., Nantes, France. Wageningen Acad. Publ., Wageningen, the Netherlands.

Brownell, J. 1996. Quinagolide (Norprolac): A novel non-ergot prolactin inhibitor. Drugs Today (Barc) 32:1-31.

Capuco, A. V., S. E. Ellis, S. A. Hale, E. Long, R. A. Erdman, X. Zhao, and M. J. Paape. 2003. Lactation persistency insights from mammary cell proliferation studies. J. Anim. Sci. 81:18-31.

Capuco, A. V., D. L. Wood, R. Baldwin, K. Mcleod, and M. J. Paape. 2001. Mammary cell number, proliferation, and apoptosis during a bovine lactation: Relation to milk production and effect of bST. J. Dairy Sci. 84:2177-2187.

Collier, R. J., L. L. Hernandez, and N. D. Horseman. 2012. Serotonin as a homeostatic regulator of lactation. Domest. Anim. Endocrinol. 43:161-170. http://dx.doi.org/10.1016/j.domaniend.2012.03.006.

Cregan, M. D., Y. Fan, A. Appelbee, M. L. Brown, B. Klopcic, J. Koppen, L. R. Mitoulas, K. M. E. Piper, M. A. Choolani, Y.-S Chong, and P. E. Hartmann. 2007. Identification of nestin-positive putative mammary stem cells in human breastmilk. Cell Tissue Res. 329:129-136. http://dx.doi.org/10.1007/s00441-007-0390-x.

Dahl, G. E., B. A. Buchanan, and H. A. Tucker. 2000. Photoperiodic effects on dairy cattle: A review. J. Dairy Sci. 83:885-893.

Dahl, G. E., and D. Petitclerc. 2003. Management of photoperiod in the dairy herd for improved production and health. J. Anim. Sci. 81:11-17.

Dahl, G. E., S. Tao, and I. M. Thompson. 2012. Lactation Biology Symposium: Effects of photoperiod on mammary gland development and lactation. J. Anim. Sci. 90:755-760. http://dx.doi. org/10.2527/jas.2011-4630.

Delbecchi, L., N. Miller, C. Prud'homme, D. Petitclerc, G. F. Wagner, and P. Lacasse. 2005. 17ß-estradiol reduces milk synthesis and increases stanniocalcin gene expression in the mammary gland of lactating cows. Livest. Prod. Sci. 98:57-66. http://dx.doi. org/10.1016/j.livprodsci.2005.10.010.

Dessauge, F., V. Lollivier, B. Ponchon, R. Bruckmaier, L. Finot, S. Wiart, E. Cutullic, C. Disenhaus, S. Barbey, and M. Boutinaud. 2011. Effects of nutrient restriction on mammary cell turnover and mammary gland remodeling in lactating dairy cows. J. Dairy Sci. 94:4623-4635. http://dx.doi.org/10.3168/jds.2010-4012.

Feng, S., A. M. Salter, T. Parr, and P. C. Garnsworthy. 2007. Extraction and quantitative analysis of stearoyl-coenzyme A desaturase mRNA from dairy cow milk somatic cells. J. Dairy Sci. 90:41284136.

Flint, D. J., and C. H. Knight. 1997. Interactions of prolactin and growth hormone $(\mathrm{GH})$ in the regulation of mammary gland function and epithelial cell survival. J. Mammary Gland Biol. Neoplasia 2:41-48.

Hassiotou, F., and P. E. Hartmann. 2014. At the dawn of a new discovery: The potential of breast milk stem cells. Adv. Nutr. 5:770-778. http://dx.doi.org/10.3945/an.114.006924.

Hernandez, L. L., J. L. Collier, A. J. Vomachka, R. J. Collier, and N. D. Horseman. 2011. Suppression of lactation and acceleration of involution in the bovine mammary gland by a selective serotonin reuptake inhibitor. J. Endocrinol. 209:45-54. http://dx.doi. org/10.1530/JOE-10-0452.

Hernandez, L. L., C. M. Stiening, J. B. Wheelock, L. H. Baumgard, A. M. Parkhurst, and R. J. Collier. 2008. Evaluation of serotonin as a feedback inhibitor of lactation in the bovine. J. Dairy Sci. 91:1834-1844. http://dx.doi.org/10.3168/jds.2007-0766.

Ho, F., R. L. C. Wong, and J. W. M. Lawton. 1979. Human colostral and breast milk cells: A light and electron microscopic study. Acta Paediatr. Scand. 68:389-396.

Hurley, W. L. 1989. Symposium: Mammary gland function during involution and the declining phase of lactation-Mammary gland function during involution. J. Dairy Sci. 72:1637-1646.

Janjanam, J., M. Jamwal, S. Singh, S. Kumar, A. K. Panigrahi, G. Hariprasad, M. K. Jena, V. Anand, S. Kumar, J. K. Kaushik, A K. Dang, M. Mukesh, B. P. Mishra, A. Srinivasan, V. S. Reddy, and A. K. Mohanty. 2013. Proteome analysis of functionally differentiated bovine (Bos indicus) mammary epithelial cells isolated from milk. Proteomics 13:3189-3204. http://dx.doi.org/10.1002/ pmic.201300031.

Knight, C. H. 2001. Overview of prolactin's role in farm animal lactation. Livest. Prod. Sci. 70:87-93.

Knight, C. H., and M. Peaker. 1984. Mammary development and regression during lactation in goats in relation to milk secretion. Q. J. Exp. Physiol. 69:331-338.

Knight, T. W., D. S. Atkinson, N. A. Haack, C. R. Palmer, and K. H. Rowland. 1993. Effects of suckling regime on lamb growth rates and milk yields of Dorset ewes. N. Z. J. Agric. Res. 36:215-222. http://dx.doi.org/10.1080/00288233.1993.10417756.

Komara, M., M. Boutinaud, H. Ben Chedly, J. Guinard-Flament, and P. G. Marnet. 2009. Once-daily milking effects in high-yielding Alpine dairy goats. J. Dairy Sci. 92:5447-5455. http://dx.doi. org/10.3168/jds.2009-2179.

Lacasse, P., V. Lollivier, R. M. Bruckmaier, Y. R. Boisclair, G. F. Wagner, and M. Boutinaud. 2011. Effect of the prolactin-release inhibitor quinagolide on lactating dairy cows. J. Dairy Sci. 94:1302-1309. http://dx.doi.org/10.3168/jds.2010-3649.

Lacasse, P., V. Lollivier, F. Dessauge, R. M. Bruckmaier, S. Ollier, and M. Boutinaud. 2012. New developments on the galactopoietic role of prolactin in dairy ruminants. Domest. Anim. Endocrinol. 43:154-160. http://dx.doi.org/10.1016/j.domaniend.2011.12.007.

Leitner, G., E. Shoshani, O. Krifucks, M. Chaffer, and A. Saran. 2000. Milk leucocyte population patterns in bovine udder infection of different aetiology. J. Vet. Med. B Infect. Dis. Vet. Public Health 47:581-589.

Li, P., P. S. Rudland, D. G. Fernig, L. M. B. Finch, and C. J. Wilde. 1999. Modulation of mammary development and programmed cell death by the frequency of milk removal in lactating goats. J. Physiol. 519:885-900. 
Littlejohn, M. D., C. G. Walker, H. E. Ward, K. B. Lehnert, R. G. Snell, G. A. Verkerk, R. J. Spelman, D. A. Clark, and S. R. Davis. 2010. Effects of reduced frequency of milk removal on gene expression in the bovine mammary gland. Physiol. Genomics 41:21-32. http://dx.doi.org/10.1152/physiolgenomics.00108.2009.

Lollivier, V., P. Lacasse, J. Angulo Arizala, P. Lamberton, S. Wiart, J. Portanguen, R. Bruckmaier, and M. Boutinaud. 2015. In vivo inhibition followed by exogenous supplementation demonstrates galactopoietic effects of prolactin on mammary tissue and milk production in dairy cows. J. Dairy Sci. Accepted.

Matsuda, M., T. Imaoka, A. J. Vomachka, G. A. Gudelsky, Z. Hou, M. Mistry, J. P. Bailey, K. M. Nieport, D. J. Walther, and M. Bader.. 2004. Serotonin regulates mammary gland development via an autocrine-paracrine loop. Dev. Cell 6:193-203.

Mollett, T. A., R. E. Erb, E. L. Monk, and P. V. Malven. 1976. Changes in estrogen, progesterone, prolactin and lactation traits associated with injection of estradiol-17 $\mathrm{b}$ and progesterone into lactating cows. J. Anim. Sci. 42:655-663.

Morgante, M., S. Ranucci, M. Pauselli, C. Casoli, and E. Duranti. 1996. Total and differential cell count in milk of primiparous Comisana ewes without clinical signs of mastitis. Small Rumin. Res. 21:265-271.

Negrao, J. A., P.-G. Marnet, and J. Labussière. 2001. Effect of milking frequency on oxytocin release and milk production in dairy ewes. Small Rumin. Res. 39:181-187.

Nguyen, D. A., and M. C. Neville. 1998. Tight junction regulation in the mammary gland. J. Mammary Gland Biol. Neoplasia 3:233246.

Nguyen, D. A., A. F. Parlow, and M. C. Neville. 2001. Hormonal regulation of tight junction closure in the mouse mammary epithelium during the transition from pregnancy to lactation. J. Endocrinol. 170:347-356.

Olazabal, I., J. Munoz, S. Ogueta, E. Obregon, and J. P. Garcı-Ruiz. 2000. Prolactin (PRL)-PRL receptor system increases cell proliferation involving JNK (c-Jun amino terminal kinase) and AP-1 activation: Inhibition by glucocorticoids. Mol. Endocrinol. 14:564-575.

Pai, V. P., and N. D. Horseman. 2011. Multiple cellular responses to serotonin contribute to epithelial homeostasis. PLoS ONE 6:e17028.

Peters, R. R., L. T. Chapin, R. S. Emery, and H. A. Tucker. 1981. Milk yield, feed intake, prolactin, growth hormone, and glucocorticoid response of cows to supplemented light. J. Dairy Sci. 64:1671-1678.

Rémond, B., and D. Pomiès. 2005. Once-daily milking of dairy cows: A review of recent French experiments. Anim. Res. 54:427-442. http://dx.doi.org/10.1051/animres:2005040.

Russo, V. M., A. W. N. Cameron, F. R. Dunshea, A. J. Tilbrook, and B. J. Leury. 2013. Artificially extending photoperiod improves milk yield in dairy goats and is most effective in late lactation. Small Rumin. Res. 113:179-186. http://dx.doi.org/10.1016/j. smallrumres.2013.01.002.

Shuster, D. E., R. J. Harmon, J. A. Jackson, and R. W. Hemken. 1991. Suppression of milk production during endotoxin-induced mastitis. J. Dairy Sci. 74:3763-3774.

Sorg, D., A. Potzel, M. Beck, H. H. D. Meyer, E. Viturro, and H. Kliem. 2012. Effects of cell culture techniques on gene expres- sion and cholesterol efflux in primary bovine mammary epithelial cells derived from milk and tissue. In Vitro Cell. Dev. Biol. Anim. 48:550-553. http://dx.doi.org/10.1007/s11626-012-9544-6.

Stefanon, B., M. Colitti, G. Gabai, C. H. Knight, and C. J. Wilde. 2002. Mammary apoptosis and lactation persistency in dairy animals. J. Dairy Res. 69:37-52.

Stein, T., N. Salomonis, and B. A. Gusterson. 2007. Mammary gland involution as a multi-step process. J. Mammary Gland Biol. Neoplasia 12:25-35. http://dx.doi.org/10.1007/s10911-007-9035-7.

Stelwagen, K., S. R. Davis, V. C. Farr, C. G. Prosser, and R. A. Sherlock. 1994. Mammary epithelial cell tight junction integrity and mammary blood flow during an extended milking interval in goats. J. Dairy Sci. 77:426-432.

Stelwagen, K., V. C. Farr, S. R. Davis, and C. G. Prosser. 1995. EGTA-induced disruption of epithelial cell tight junctions in the lactating caprine mammary gland. Am. J. Physiol. 269:R848-R855.

Stelwagen, K., V. C. Farr, H. A. McFadden, and S. R. Davis. 1997 Time course of milk accumulation-induced opening of mammary tight junctions and blood clearance of milk components. Am. J. Physiol. 273:R379-R386.

Stelwagen, K., H. A. McFadden, and J. Demmer. 1999. Prolactin, alone or in combination with glucocorticoids, enhances tight junction formation and expression of the tight junction protein occludin in mammary cells. Mol. Cell. Endocrinol. 156:55-61.

Stull, M. A., V. Pai, A. J. Vomachka, A. M. Marshall, G. A. Jacob, and N. D. Horseman. 2007. Mammary gland homeostasis employs serotonergic regulation of epithelial tight junctions. Proc. Natl. Acad. Sci. USA 104:16708-16713

Wagner, S. A., D. E. Jones, and M. D. Apley. 2009. Effect of endotoxic mastitis on epithelial cell numbers in the milk of dairy cows. Am. J. Vet. Res. 70:796-799.

Wall, E. H., and T. B. McFadden. 2012. Triennial lactation symposium: a local affair: How the mammary gland adapts to changes in milking frequency. J. Anim. Sci. 90:1695-1707.

Watson, C. J. 2006. Involution: Apoptosis and tissue remodelling that convert the mammary gland from milk factory to a quiescent organ. Breast Cancer Res. 8:203.

Werner-Misof, C., M. W. Pfaffl, H. H. D. Meyer, and R. M. Bruckmaier. 2007. Effect of chronic oxytocin-treatment on the bovine mammary gland immune system. Vet. Med. (Praha) 52:475-486.

Wilde, C. J., C. Knight, and D. J. Flint. 1999. Control of milk secretion and apoptosis during mammary involution. J. Mammary Gland Biol. Neoplasia 4:129-136.

Yadav, P., P. Kumar, M. Mukesh, R. S. Kataria, A. Yadav, A. K. Mohanty, and B. P. Mishra. 2015. Kinetics of lipogenic genes expression in milk purified mammary epithelial cells (MEC) across lactation and their correlation with milk and fat yield in buffalo. Res. Vet. Sci. 99:129-136. http://dx.doi.org/10.1016/j.rvsc.2015.01.003.

Yart, L., F. Dessauge, L. Finot, S. Barbey, P. G. Marnet, and V. Lollivier. 2012. Ovariectomy improves lactation persistency in dairy cows. J. Dairy Sci. 95:3794-3802. http://dx.doi.org/10.3168/ jds.2011-5195 